\title{
15
}

\section{Probably not the last prophet}

The explanation we offered for the Noise and the Cemetery Cult in Chapter 6 is an awkward fit for Wind Nation. We begin this final chapter by addressing that issue. Although the drama of European colonial contact-including an extraordinary encounter with white material prowess in World War II-was an important factor in the Manus cargo millenarianism of the 1940s, we cannot say this of Wind Nation. Nor, we will argue, are such encounters necessary precursors of other cargo cults. In this chapter we also argue that anthropologists and others probably have placed too much emphasis on the relationship between political subjugation, social disruption, and various other forms of human travail and millenarianism in general. Millenarian doctrines themselves can encourage susceptible people to distil their vague discontents into potent perceptions of affliction that would not trouble less susceptible people. But what determines people's susceptibility? In this chapter we argue that a strong inclination to personify causation—and, as discussed in Chapter 2, to assume a guiding purpose in events or a grand design in history, thus denying chance a significant role-increases susceptibly to millenarianism. ${ }^{1}$ Such inclinations generally rest on perceptions of our species as 'being the center of malign or benign attention' (Schwartz 1973: 169). Such perceptions are the essence of a paranoid ethos, which, we argue, contributes mightily to millenarian susceptibility.

1 In Chapter 2 we suggested that positing a telos in history could be considered an attenuated or veiled form of personifying causation. 
The concept of religion as generally used merely hints at the phenomena critical to millenarianism. As we discussed in Chapter 2, doctrines and practices resting on cosmologies of animate and personal causation encompass much of what anthropologists gloss as religion, but the tendency to personify causation embraces a much larger sphere of thought and behaviour, including, to name only a few manifestations: assuming omnipresent watchful ghosts or other numerous and sentient but incorporeal entities, worshipping a single omniscient deity, postulating a creator deity that has retired from involvement in its creation (as in deism), believing in the secret sway over world history of the illuminati or other shadowy human agents, believing in a metaphysical telos for humanity or all forms of being, or mundane teleological thought. ${ }^{2}$ The ubiquity of this tendency and the tendency to see one's group or our entire species as the centre of extra-human attention and purpose ensures that Paliau will not be the last prophet of the world, perhaps not even of tiny Manus. In fact, millenarianism is thriving in much of the world, as we also discuss in this chapter.

We will also argue that to understand millenarianism better, anthropologists should put aside categories like 'religion' and 'spirituality'. (The latter is becoming disturbingly popular in the literature on Melanesia. Anthropologists sometimes substitute it for religion but this makes nothing clearer.) If we want to understand millenarianism we should focus on why it is so hard for so many human beings to understand the world in ways that do not personify causation and do not rest on the conviction that events - from the extremely local to the cosmic — unfold in dialogue with the concerns and actions of members of our species. ${ }^{3}$

2 Aficionados of science fiction will see how well the 'Overmind', which features in Arthur C. Clarke's (1953) Childhood's End, fits this list.

3 Human beings_-intentionally and incidentally — create, maintain, and alter social and cultural systems. Such systems have great causal weight. In this way people are in fact behind much that happens in the world. But there is a difference between the structural momentum of capitalism, for instance, and the conscious decisions of an individual capitalist. 


\section{Margaret Mead's Wind Nation}

We began this book with a story featuring Margaret Mead, so it is fitting that we approach this chapter's first topic-problems in understanding Wind Nation-with another story about Mead. Many Pere village people remember Mead as a supporter of or even a partner with Paliau in promoting wider cooperation in largely secular efforts to improve their lives. This undoubtedly would have pleased Mead. But Wind Nation has recruited Mead posthumously. This probably would not have pleased her.

Square wooden posts hold up the roof over the concrete verandah of Margaret Mead's Resource Center (MMRC) in the middle of Pere. The sides of each post are divided into vertical rectangles, each of which is decorated with a carving in shallow relief, painted in red, black, and white. A number of these panels are decorated with Wind Nation iconography, including a chambered nautilus shell-or kalopeu, the symbol of Makasol and subsequently of Wind Nation-and a simplified version of the Wind Nation logo. Several villagers confirmed that these were indeed Wind Nation images and they seemed to find nothing odd about it.

Smith, however, found this puzzling. It also puzzled him that numbers of Pere people spontaneously told him about Mead's and Paliau's close relationship because he knew that Mead had met Paliau on only a few occasions. Several Manus people have promulgated highly critical views of Mead's work in Manus. ${ }^{4}$ But in Pere in 2015, Smith heard only appreciation of how Mead and Paliau had been collaborators in the same cause: uniting people and promoting cooperation. Speaking of how Pere combined with other Titan communities to become a consolidated village, the Pere village magistrate told Smith 'Paliau created it and Margaret Mead supported it' (Paliau i kirapim na Makret Mit i sapotim). And Kumulau Paniu told Smith that 'Margaret Mead was close with Paliau. The two walked together' (Makret Mit i pas wantaim Paliau. Tupela i wokabaut wantaim). ${ }^{5}$

4 The best-known examples appear in the 1992 volume Confronting the Margaret Mead Legacy: Scholarship, Empire, and the South Pacific, edited by Lenora Foerstel (formerly Lenora Shargo) and Angela Gilliam; and the 1983 film Papua New Guinea: Anthropology on Trial, produced and directed by Barbara Gullahorn-Holecek for WGBH, Boston.

5 Paniu may well have meant 'walked together' metaphorically. In Tok Pisin, 'walked together' (wokabaut wantaim) sounds more metaphorical than it does in English — but whether meant literally or metaphorically this is still a significant statement. 


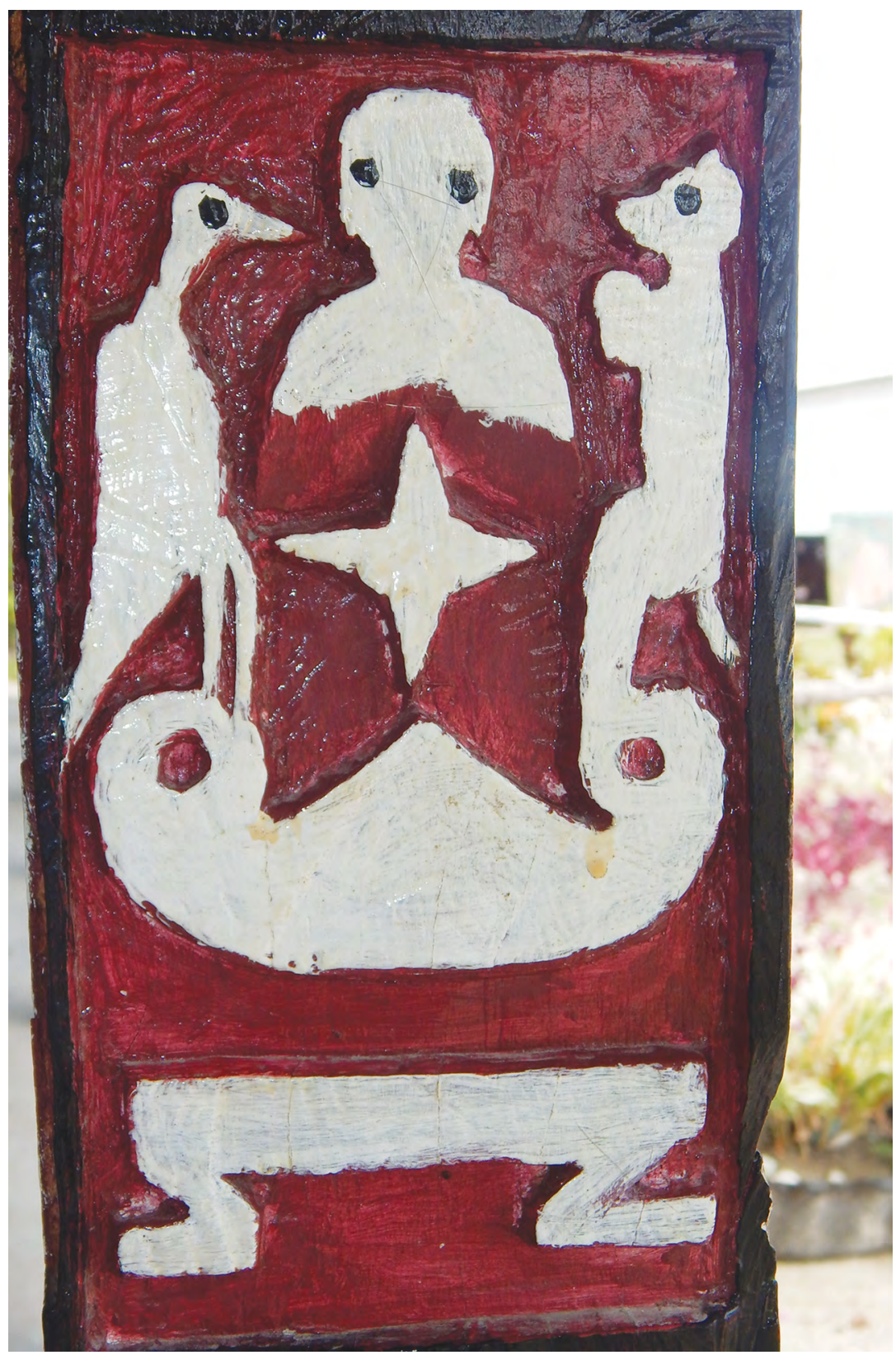

Figure 15.1: An image of the Wind Nation logo is carved on one of the posts of Margaret Mead's Resource Center in Pere village, shown here in 2015.

Source: Michael French Smith. 
A few people who spoke to Smith of Mead and Paliau made implausible claims. For example, one or two said that Mead had helped Paliau create the consolidated Pere village in the early days of the New Way, even though the New Way village was built in the years between Mead's and Reo Fortune's stay in old Pere in 1928 and Mead's return in 1953. But other claims have a firmer basis. The retired Air Niugini executive we mentioned in Chapter 14 said that Mead and Paliau 'agreed on things, worked together'. To the best of our knowledge they did not work together in person, but they did agree that people should cooperate and remain united. Inspiring wider cooperation was among the accomplishments of the Paliau Movement Mead most admired, which she almost certainly would have praised when speaking with Pere people. ${ }^{6}$ This is a plausible basis for mentioning Paliau and Mead in the same admiring breath.

But this does not explain fully why Wind Nation seems to be claiming Mead through literally putting its mark on the MMRC. Probably, in the manner of Paliau, Wind Nation strives to put its stamp on anything that might raise its profile and enhance its legitimacy. ${ }^{7}$ Of course, it is also possible that when in 1967 Mead told the people of Pere to follow the example of the people of 1946 (described below), those who still saw Paliau as a divinely inspired prophet took her to mean that they should pursue millenarian renewal. (Recall that during the Cemetery Cult, some of its proponents justified their activities by saying that they were merely returning to the 'good ways of 1946'.) This would not make Mead happy. Her desire that villagers not think she condoned a cargo cult-and, perhaps, her desire not to know about it—kept her from investigating the Cemetery Cult going on around her in 1953. A couple of people also said they'd seen pictures of Mead and Paliau together and one woman said she had seen Mead and Paliau together in a video. Only later did Smith recall that Mead and Paliau both appeared in a film of Mead's 1967 visit to Pere, her last, Margaret Mead's New Guinea Journal..$^{8}$ The film was made for the United States National Educational Television Network and

6 Maintaining social harmony is a chronic concern in many small communities in which people not only rely on each other for material aid but also personify the causes of misfortune. Smith (1994) discusses this issue at length.

7 We do not know, however, if the adherents who made the Wind Nation carvings on the MMRC met with any resistance. The few people Smith asked about this said that they did not, but the story may be more complicated.

8 The film makes it appear that in 1967 Mead is returning to Pere after an extended absence. She had spent considerable time in Pere, however, in 1964-65. 
released in 1969. ${ }^{9}$ It was shown on American and Australian television and it undoubtedly reached Papua New Guinea (PNG), although probably as a video cassette, since even today there is still almost no access to broadcast television in PNG outside urban areas. The film focuses on Mead's history with Pere but gives a lot of time to the Paliau Movement (minimising the millenarian episodes of the 1940s and 1950s, just as Mead's (2001 [1956]) New Lives for Old does). There is also footage of Paliau speaking in the House of Assembly in Tok Pisin (with great clarity and dignity) and-most germane to people's memories of a Mead-Paliau connection-several minutes showing a feast in Pere honouring Mead during her 1967 visit. Paliau is shown moving among the guests, in white shirt and tie, although he is not shown interacting with Mead. But in her remarks to the guests (in Tok Pisin) Mead heaps praise on him. 'Paliau has set an example', she says. Mead also admonishes those assembled to follow the example of 'the people of 1946' who started the changes she has seen in Pere. ${ }^{10}$

It probably would not mollify Mead to know that calling Wind Nation a cargo cult may not be strictly accurate. ${ }^{11}$ There is a straight line from the millenarian elements of the early Paliau Movement to Wind Nation's millenarianism. We are not interested in debating exactly where to draw a line between cargo cults and other forms of millenarianism, but there are undeniable differences between the Noise and the Cemetery Cult and Wind Nation. It resembles the Noise and the Cemetery Cult in its promise of material abundance, both through control of the stuff of immediate material wellbeing in rural PNG (weather, wildlife, crop fertility) and through magical access to manufactured goods through

9 Nancy C. Lutkehaus examines responses to Margaret Mead's New Guinea Journal in her 2008 volume, Margaret Mead: The Making of an American Icon.

10 What Mead said in Tok Pisin ('ol man bilong 1946) means, at its most literal, 'the men of 1946'. But it can also refer to people in general.

11 Mead could not have opposed all millenarianism, for she was a practising Christian. As Hunt (2001: 2) writes: 'The millennium dream is therefore at the center of the faith and consistent with its principal dogmas'. But Mead was quite an orthodox Christian, and-as Hunt also writes: 'It is the preoccupation with the millennium to come ... which separates the fanatics and the heretics from the rest of Christendom'. 
the power of thought. ${ }^{12}$ But the manufactured goods-the cargo-will not come in ships or planes piloted by returning ancestors or under the command of Jesus. Further, Wind Nation doctrine-if not every Wind Nation adherent-has turned away from blaming the condition of black Melanesians on white greed and towards an almost syrupy vision of universal human unity.

Neither are the central features of Wind Nation doctrine uniquely or even distinctively Melanesian. Stephen Pokawin (1983b: 112) was not far from the mark when he wrote that 'the only indigenous aspect of it is the people. The ideas, religiously speaking, are not original'. In fact, many Americans will find some of the ideas extremely familiar, such as the notion that one can control reality with one's thoughts. This assumption (or desperate hope) has played such a large role in American life that Adam Morris calls it 'the unofficial national religion of the United States'. Morris (2019: 197-8) describes how in the late nineteenth and early twentieth centuries it loosely united a number of movements under the rubric 'New Thought'. Today, it is central to the stock in trade of many popular purveyors of self-help programs, such as Tony Robbins and Oprah Winfrey. The idea of controlling reality by thinking is so attractive that it probably has seized people's imaginations independently in many times and places. ${ }^{13}$ Similarly, the signs of Paliau's return-things people have never seen, heard, or said before-could have come straight from a generic manual for prophecy, and they could easily have been adapted from Pope Gregory's seventh-century letter to Æthelbert of Kent, advising him that 'as the end of the world draws near, many things are to come

12 This is one of the most dramatic ways in which Wind Nation resembles the Noise and the Cemetery Cult. Without further research it is hard to say if there is something typically Melanesian or more widespread about the extremity of their emphasis on attaining a form of existence devoid of virtually all effort. Schwartz (1976a: 197) wrote of Manus: 'A surprisingly large range of human activities are termed "work", so that one is led to think of an effort syndrome. This is probably widespread [in PNG], to judge from the reflexes in Pidgin English. Ceremonial exchange in all its phases is "work"; even sexual intercourse and the production of babies, which requires multiple inseminations to fill the womb, is considered to be very hard work ... In the light of these conceptions of "work", the attractiveness of the no-work cargo state is evident'. See Smith $(1982,1994)$ for relevant discussion of conceptions of work on Kairiru Island, East Sepik Province.

13 Omnidirectional diffusion could also be at work. Tuzin's (1997) study of the remarkably wide distribution of versions of the Swan Maiden myth provides a fascinating example of the distances over which cultural motifs circulated long before the advent of modern communications media. Tuzin also makes the point that diffusion is a process of selection and naturalisation, thus not utterly divorced from independent invention (1997: 73-4). Some versions of control by thought, however, are definitely indigenous to Melanesia. Recall the idea that inappropriate thoughts can doom an enterprise - as the old woman's thoughts of affinal exchange caused a boat returning from Cemetery Cult activities on Johnston Island to swamp over the reef (described in Chapter 8). 
upon us which were not before'. But Wind Nation (as Smith observed it in 2015) least resembles what we might call classical cargo cults-like the Noise or the Cemetery Cult_-in apparently placing as much emphasis on creating an enduring organisation as it does on speeding the arrival of the cargo.

\section{Problems in explaining Wind Nation}

Despite the relatively staid face of Wind Nation of late, it would be foolhardy to assert that never again will rumours of the imminence of a new world of never-ending ease and abundance spread through Manus like fire. We say this even though the circumstances under which the Noise and the Cemetery Cult arose no longer pertain in Manus. Nor did they pertain for the young men who aided and abetted Paliau in creating Wind Nation from the mid-1970s until Paliau's death. Their lives in the late twentieth century differed greatly from those of the proponents of the Noise and the Cemetery Cult. They had not lived under colonial rule and they had not looked up from mending fishing nets on the porches of thatched lagoon houses to see the massed mechanical power and unimaginable material wealth of the American military arriving by sea and air. They were not illiterate or nearly so. Rather, they had received many years of formal schooling, served in responsible government jobs, visited some of the world's modern cities, and enjoyed the luxuries of electric light, plumbing, refrigeration, and air travel. Nevertheless, they became eager millenarians.

The sudden and dramatic devaluation of the forms of wealth that underwrote status and self-worth in indigenous Manus society was a key element in the explanation we offered for Manus people's passion for the Noise and the Cemetery Cult. But this has tenuous relevance for the majority of today's Wind Nation adherents. Wind Nation proponent Kakak Kais exaggerates when he writes that 'Paliau's vision for his people to experience the comforts similar to that of the white man has been achieved to a great extent' (Kais 1998: Chapter 2) and they are now 'enjoying the white man's material wealth' (ibid.: Chapter 3). As of 2019, the United Nations Development Programme Human Development Index ranked PNG 155 out of 189 countries on the basis of life expectancy at birth, years of schooling, and gross national income per capita. (African countries comprised most of the other occupants of the 'Low Human 
Development' category. $)^{14}$ There is obvious poverty in Manus, but Smith met young men with considerable formal schooling, working in modern institutions (such as the PNG National Broadcasting Corporation), who are enthusiastic Wind Nation adherents. Many Manus people are acutely aware of differences in wealth and power among the world's nations. But the most glaring inequality many Papua New Guineans are likely to experience firsthand is that between a small, mostly urban indigenous elite and the PNG rural masses. Many members of the latter find this intramural division especially galling. But Wind Nation doctrine does not directly invoke either international or domestic inequity. ${ }^{15}$ Why, then, Wind Nation? This question requires us to consider the problem of explaining millenarianism in general.

\section{Not necessarily religions of the oppressed}

It is probably impossible to identify the circumstances that give rise to millenarian thought and action without either defining millenarianism very narrowly or settling on circumstances that are, or border on, universal. Stephen Hunt (2001: 2), for instance, opines that 'the millennial vision of a new order may be said, to some extent at least, to be part of the human condition'. Burridge (1969: 117) defines the 'central issue' of millenarianism as 'the ennoblement of the nature of man'. He therefore concludes that 'there are no known conditions which would render millenarian activities unnecessary. ${ }^{16}$ (Our data on the Noise and the Cemetery Cult, however, show that at least some participants were primarily interested in ennobling themselves.)

14 www.hdr.undp.org/; scroll down to the Latest Human Development Index (HDI) Ranking.

15 It is possible that such themes are not entirely absent. During the years covered by our research, however, they did not come to our attention.

16 Burridge attempts greater specificity, however, in another work. He writes (1995 [1960]: xxiii) there is not a simple relationship between conditions obtaining and the occurrence of a cult. We can only say that under certain conditions a Cargo cult might occur. The catalytic spark which explodes into a cult cannot be pinned to a where or a when. Nevertheless, the general conditions, the moral problems to which a Cargo cult could be seen as a response, have grown out of a series of events and circumstances which may be reasonably well defined. Many of the old customs, institutions, and modes of behaviour which together constituted viable frameworks of traditional and trusted ways of life are either fast disappearing or have already died out. Those that remain seem not to be adequate to the environment in which the people concerned now find themselves, and fresh institutions must take the places of those that have gone'. 
Most pronouncements on the roots of millenarianism are less extravagant then Burridge's. Many, however, assume that millenarianism is rooted in circumstances from which most societies are seldom if ever entirely free. They point to almost any variety of disruption of the existing social order-such as economic collapse, culture contact, or rapid technological change—or simply the perceived threat of disruption. ${ }^{17}$ Landes (2011: xvii) is wise to reject the possibility of a predictive model of the conditions under which millenarian impulses result in at least temporarily viable movements. He writes: 'Historians and sociologists have often attempted causal and predictive models for millennialism. But what leads one movement to "take" and many another to fizzle seems more appropriate for chaos theory than historical and social "logic" alone; and anything more "scientific" is just hindsight'. Landes (2011: 104) also writes: 'It is always hard to assess the motivations for adherence to millenarian prophecies. The general distribution tends to favor a rough split along hierarchical lines. Those with more power, more investment in "the world" and public space tend to dislike prophecies that claim that their world is "about to pass away" ... Thus the poor, the dispossessed, women, and educated people who feel they should run the world but do not, form an important component of almost all these millennial movements'.

Nonetheless, Landes goes on to list many exceptions to that general rule. But are not millenarian movements 'religions of the oppressed', as Vittorio Lanternari (1963) famously characterised what he called 'modern messianic cults'? That millenarianism is a response to oppression is probably the most common generalisation both scholars and lay people put forward. It has been part of the literature on Melanesian movements for over 100 years. Burridge (1969: 3) cites E.W. Chinnery and A.C. Haddon-two of the earliest European students of Melanesian millenarianism-on the nature of millenarianism in general: 'An awakening of religious activity is a frequent characteristic of periods of social unrest ... Communities that feel themselves oppressed anticipate the emergence of a hero who will restore their prosperity and prestige' (Chinnery and Haddon 1917: 455). Yet Burridge (1969: 13) finds invoking oppression perpetrated by outsiders too easy. He writes that 'a dissatisfaction with the current system' is a 'precondition' of millenarian action. But, he continues, 'if we describe this precondition as "feeling oppressed", the "oppression" does not necessarily

17 Roseanne Roseannadanna, as portrayed by Gilda Radner from 1977 to 1980 on the longrunning television program Saturday Night Live, made a similar point: 'it just goes to show you, it's always something — if it ain't one thing, it's another'. 
derive from an external political control: it may be rooted in internal dissatisfactions with present assumptions, rules and modes of redemption'. From his review of the cargo cult literature, Trompf (1994: 161) also concludes that it is a mistake to assume too much about the role of external forces in precipitating millenarianism. He writes: 'It is false to conclude that the intensity of cargo cultism or the degrees of its incidence are directly proportional to the amount of outside exploitation or interference'.

Writing specifically of Christian millenarianism, Hamilton (2001: 16) questions assumptions that early Christianity drew much of its force from its appeal to the economically disadvantaged: 'That the early Christians were recruited from among the poorest sections of the community is, of course, the traditional view, but it is one upon which much doubt has been cast by recent research'. ${ }^{18}$ Similarly, Bronwen Douglas (2001: 626) concludes that 'the ethnographic fit' between 'a sense of present crisis' and 'eschatological anticipation' in PNG is 'suggestive but ambiguous and highly incomplete'. Addressing millenarianism in today's America, anthropologists Kathleen Stewart and Susan Harding (1999: 286) are unable to label it as primarily a response to economic or social deprivation. They write: 'an apocalyptic/millennial sensibility ... has come to inhabit and structure modern American life across a wide range of registers'. Philip Lamy (1996) concludes that 'millennium rage' and 'doomsday prophecy' among American survivalists and white supremacists are linked to rapid social change. But Lamy also finds that 'apocalyptic beliefs' that were once more common at the margins of Western society now inform 'the millennial rage of the middle-class sectors of our modern industrial societies' (Lamy 1996: 256) and that 'millennium rage reaches ... into the American popular culture' (ibid.: 264), as he amply illustrates. Kate Bowler (2013: 216-21) presents evidence against the assumption that the American prosperity gospel is 'a poor people's movement, an expression of believers' longing for (and distance from) socio-economic stability' (Bowler 2013: 232). We have to conclude that some millenarian movements may well be 'religions of the oppressed', but many are not.

Further, the kind of conspiracy thinking so typical of millenarianism is 'now as characteristic of the center' as of 'marginal groups' (Stewart and Harding 1999: 293). Joseph E. Uscinski and Joseph M. Parent (2014: 11)

18 Citing Holger Jebens (2000: 191), Bronwen Douglas (2001: 628) emphasises that 'eschatology, whether indigenous or Christian, is not only a reflex of catastrophe or a sign of crisis but may be the very reverse'. For instance, following Philip Gibbs (1977), she observes that people may take a 'sense of relative plenitude' as a precursor of fulfilment of a millenarian hope. 
grapple with the closely related issue of the relationship between stressinduced, for instance, by natural disasters or economic uncertainty-and conspiracy thinking (the tendency, as they put it, 'to see nonexistent patterns and evoke conspiratorial explanations') and they reach a similar conclusion: 'Conspiratorial beliefs are common and consistent; major disasters are not'.

\section{An alternative to philanthropic interpretation}

Modern anthropology's commitment to showing the world's dominant peoples that other ways of life are reasonable, legitimate, and should not be trampled upon has undoubtedly helped incline anthropologists towards portraying cargo and other forms of millenarianism as reactions to oppression or in some other way politically progressive (cf. Trompf 1991: 191). The majority of interpretations found in the literature lean hard in the direction of what Burridge (1995 [1960]: 128-9) calls 'philanthropic' explanation. Philanthropic explanations seek, in Burridge's words, to 'emphasize those features of millenarian movements which reveal economic and political problems ... Millenarian movements are regarded as expressive of economic difficulties and political discontents'. Such interpretations are not necessarily wrong in specific cases, but they strongly encourage tautology. That is, they tempt people to assume that where there is millenarianism there must be more than the usual quota of human suffering. There is, of course, no way to measure levels of suffering and compare them with levels of, for example, cargo cult activity.

A philanthropic bias may also help account for the popularity among anthropologists of the idea that cargo cults help unify people (e.g. Eriksen 2010: 69; Kaima 1991; May 1982; Worsley 1968 [1957]). This is not what we found regarding the millenarianism within the Paliau Movement. Paliau was able to unify people to support the Movement program in part because some hoped that even his most prosaic projects were steps on a millenarian path. The outbreaks of explicit millenarian action within the Movement (the Noise and the Cemetery Cult), however, undermined Movement unity. Ironically, only by failing dramatically did the Noise provide Paliau with an opportunity to build wider unity, as described in Chapter 7. Landes (2011: 108-12) also provides a good example of a case in which millenarian unity was superficial and left faction in its wake. Although summary descriptions of the Xhosa cattle slaying in mid- 
nineteenth-century Africa often make it sound like a mass movement, there was, Landes writes, a considerable contest between believers and unbelievers. The influence of the Xhosa chiefs was a critical factor in getting people-even sceptics - to cooperate. But Landes reports that 'struggle between believers and unbelievers marks the sociability of the Xhosa to this day'.

Joel Robbins (2011) takes philanthropic explanation of Melanesian millenarianism in a different direction. He observes that 'even when they live outside full-scale millenarian movements, many Melanesians live with a kind of millenarian openness' that Robbins calls 'everyday millenarianism' (pp. 183-4). They 'go about their normal business but remain ready for unexpected change, anxious to hear a messianic promise should it be made'. In this frame of mind, 'the present ceases to govern one's sense of possibility' (p. 191). Following themes in the work of Jacques Derrida and Walter Benjamin, Robbins finds here an admirable receptivity to the possibility of a radically different and better future, perhaps something beyond any expectations modelled on the past or the present. He illustrates the potential in 'everyday millenarianism' for opening 'radically new possibilities for action' (p. 186) by telling of how a group of Urapmin people (of PNG's East Sepik Province) reacted to finding at the side of a trail a pair of new gloves. Even though 'a simple, locally sensible explanation' was readily available (p. 189), they took this novel event as 'a chance to stop and listen in case they [that is, the gloves] might be making a messianic promise' (p. 190). Maybe the gloves foretold the development of a major mine on their land, or maybe the Second Coming of Jesus, or maybe something just as wonderful but beyond their present powers of imagination. ${ }^{19}$

Robbins (2011) romanticises this incident and the kind of thinking it exemplifies. He focuses exclusively on a Wordsworthian intimation of something pleasingly extraordinary, perhaps even something 'apparelled in celestial light'. ${ }^{20}$ Yet being familiar with village life in PNG he must

19 A major mine is often anything but a blessing for local indigenes in PNG, but poor rural people sometimes see only the possibility of great wealth.

20 The quotation is from William Wordsworth's 'Ode: Intimations of Immortality from Recollections of Early Childhood'. Smith, who selected this quotation, is as fond of the English Romantic poets as anyone. But Robbins waxes so romantic that he not only ignores the dangerous potential in Urapmin 'everyday millenarianism', he also short-changes other possibilities for envisioning a radically different and better world. He does note that 'Marxism and other post-Enlightenment political ideologies' (Robbins 2011: 186) can also supply the content of messianism. But he seems enamoured of a religious vocabulary ('messianism' and, following Derrida, or his translator, 'messianicity'), which tends to undermine his gesture to the possibility of emancipatory secular imagination. 
realise that villagers are just as likely to find in novel events intimations of mortal danger from human or non-human persons-intimations that can foster fear, anger, and violence. (Readers may recall that in Chapter 3 we made a similar point regarding West's description of the world of the Gimi people of PNG.)

Despite his romanticism, Robbins identifies the factor common to all forms of millenarianism: immersion in a world of personified causation in which people perceive unusual events as personally relevant, for good or ill; that is, a world of personified causation flavoured with a paranoid ethos.

\section{It's everywhere}

Schwartz (1973: 169) took pains to emphasise the 'susceptibility of human societies, however "advanced", to social paranoia'. In Chapter 2, we also emphasised how widespread among members of our species is the tendency to personify causation. It is not surprising then, that millenarianism is common not only in history but throughout the world today, in societies however 'advanced', not excluding America.

Considerable recent literature pays special attention to what Barkun (2006 [2003]: 21) calls a 'dramatic proliferation of millenarian schemata, both in terms of the number of competing visions and in terms of their diversity', from which so-called modern societies are far from immune. ${ }^{21}$ Landes (2011) devotes considerable attention to UFO millenarianismthat is, the hope that beings from outer space will bring salvation to Earth's people. He does so, he writes, because 'they illustrate how key millennial tropes-apocalyptic scenarios filled with both outrageous hopes and fears and paranoid conspiracy thinking - continue to work on allegedly modern, enlightened minds' (Landes 2011: xii). Stewart and Harding (1999: 294) write of how 'contemporary American public and popular culture' is home to 'a proliferation of messianic cults, paramilitary groups, and racial separatists'.

21 Schwartz writes that a paranoid ethos is part of a common human heritage and 'sporadically resurgent in modern societies' (1973: 155), and he speaks of the fragility of modernity and the 'thin crust of knowledge and security that sometimes supports us above the level of the paranoid ethos'. We want to emphasise that modernity as a social and cultural bulwark against pervasive fear and insecurity is fragile. We also join other scholars in making the related point that, in Hall's phrase: 'As it is now widely understood, "modernity" is uneven in its development, incomplete in its manifestations, and hybridically connected to other social forms' (Hall 2009: 209; cf. Latour 1993). 
Stewart and Harding (1999) delve into the connection in America between millenarianism and what Barkun (2006 [2003]) and others call conspiracism. They write: 'American nationalism rests both on the millennial claim that American-style democracy and technological progress will save the world and on an apocalyptic paranoia that imagines external enemies, "thems" who are out to get "us"' (Stewart and Harding 1999: 293; cf. Jacoby 2008; Walker 2013). ${ }^{22}$ In the same vein, Barkun (2006 [2003]: 187) observes that 'conspiracists, particularly those who believe in super conspiracies, do seem to inhabit a different epistemic universe, where the usual rules for determining truth and falsity do not apply'. ${ }^{23}$ It is a world like that of the cargo cult, in which, as Schwartz (1973: 157) observes, 'suspicion and cognitive rejection' are joined with 'extreme credulity'. ${ }^{24}$

22 Note that in this passage Stewart and Harding (1999) use the term paranoia only for perceptions of being at the centre of malign attention. When we speak of a paranoid ethos we also include perceptions of being the focus of benign attention. That is, people can overestimate the personal relevance of events in positive as well as negative ways. The feeling that 'somebody up there likes me!'- a sentiment linking personification of causation with perceptions of personal relevance-is as good an example of a paranoid ethos at work as the fear that one's illness is punishment for sin. (Somebody Up There Likes Me was the title of a 1956 movie based on the life of the boxer Rocky Graziano, which probably ushered it into the American store of clichés. David Bowie also used it as a song title on his 1975 album 'Young Americans'.)

23 Scholars disagree on the extent to which today's Americans are more inclined to conspiracy thinking than those of another era. Barkun (2006 [2003]: 38) proposes: 'Although belief in malevolent plots has a long history in American culture, it is safe to say that no period has evinced so strong an appetite for conspiracism as the last twenty-five or thirty years of the twentieth century'. In contrast, Uscinski and Parent (2014: 128) write: 'Conspiracy theories never really go out of fashion. Yet if the question is when U.S. conspiracy thinking peaked, the answer is: not now and not for decades'. Their research identifies the 1890s and 1950s as 'the real ages of conspiracy in the United States. The prevalence of conspiracy talk in the United States has diminished slightly across time, especially since the mid-1960s. The most marked trend in the data, however, is stability'.

24 No one paints a darker picture of epistemological chaos in the modern world than political scientist Jodi Dean (1998) in Aliens in America: Conspiracy Cultures from Outerspace to Cyberspace. She concludes that we are already stuck with a post-truth world and had better get used to it: 'We have moved from consensus reality to virtual reality. Politics itself must now be theorised from within the widespread dispersion of paranoia that has supplanted focused targets such as "Jim Crow" laws, Richard Nixon, and the Vietnam War. Insofar as practitioners can link together varieties of disparate phenomena to find patterns of denial, occlusion, and manipulation, conspiracy theory, far from a label dismissively attached to the lunatic fringe, may well be an appropriate vehicle for political contestation' (Dean 1998: 8). Barkun (2006 [2003]: 186-7) finds Dean over the top. He suggests that 'we have not yet entered a world of complete epistemological pluralism, and it is unclear how such a world would or could function in everyday life, where mundane social, economic, and governmental business is transacted'. The Manus people trembling with the nearness of God in 1947 found out rather quickly that they could not live in the realm of millenarian fervour and epistemological upheaval for very long without getting very hungry and tired. They seem to have remembered this lesson, because participation in their next millenarian effort- the Cemetery Cultwas much more compatible with keeping themselves housed and fed. 
How does recognising that a tendency to personify causation and some degree of paranoid ethos are widespread, perhaps virtually universal, get us any closer to understanding millenarianism? The primary contribution is to shift our attention from assuming a strong relationship between millenarianism and natural disaster, social disruption, or oppression. We cannot dismiss the importance to millenarianism of social upheaval and human suffering, but we propose that the extent of peoples' immersion in a world of personified causation in which they are the focus of malign or benign attention is the critical factor in how people respond to untoward events or chronic dissatisfaction. Such scholars as Atran (2002), Barrett (2000), Boyer (2001), Guthrie (1993), and Hood (2009)—all discussed in Chapter 3-offer possible explanations for a general human tendency to personify causation. ${ }^{25}$ But it is also possible to study in particular populations the strength and pervasiveness of both personification and a paranoid ethos and the factors fostering their forms and degrees, as several works we have cited—in addition to Schwartz's—illustrate (Bailey 1971; Epstein 2000-2001; Hallowell 1955; Lepowsky 2011; Spiro 1967). There is nothing simple about this line of inquiry. For example, Barbara Andersen's (2017) research among nursing students in PNG shows howcontrary to what one might expect- their modern schooling appears to enhance their fear of occult forces.

It is important, of course, to remember that the distribution of a cultural construction of the world congenial to millenarianism is only one factor in the distribution of millenarian participation in a specific instance. We demonstrated this in our analyses of the distribution of participation in the Noise and the Cemetery Cult. Our analysis also recommends the wisdom of seeking factors in the distribution of millenarian action by observing circumstances and events over time, for we saw that advocates and opponents of the Manus cargo cults sometimes shifted roles, often for reasons other than simple attachment to a millenarian doctrine.

25 We do not take a position on their relative merits. 


\section{The future of Wind Nation}

We have followed the Paliau Movement from its beginning to the present day, focusing on the interplay within the Movement of millenarian hopes and worldly social action and on Paliau Maloat's unceasing efforts to change Manus life and remain a leader, ambitions that were not always in perfect harmony. The communitarian and egalitarian values the Movement promoted did not sweep away conflict and self-interest, but they introduced new ideals and helped usher in new ways of cooperating for the common good (as we discussed in Chapter 14 under 'Paliau's civic legacy'). The Movement also created Wind Nation, an adventure in pure millenarianism. Today's Wind Nation leaders have recast rather than questioned their illiterate elders' fundamental assumptions about the nature of the world. In particular, like their elders, they find it difficult to entertain explanations of things in terms of chance and such impersonal forces as gravity, bacteria, drought, and flood-forces that are incapable of acting intentionally in response to human thought and behaviour. Nor can they accept a social world lacking inherent order and purpose, despite having significantly greater knowledge than previous generations of Manus millenarians of the larger social world encompassing Manus and PNG. (Exploring this apparent anomaly is beyond the scope of this book. And it would require digging deeper than we have into why, as Landes [2011: xii] writes, 'key millennial tropes ... continue to work on allegedly modern, enlightened minds'. In America, many people who are comfortable with technologies inseparable from modern science are ill at ease with ideas central to modern science: that the universe operates independent of human or extra-human will and that chance shapes many events, including human events.)

We do not have the data needed to speculate on why some contemporary Manus people who admire Paliau have no interest in Wind Nation while others embrace it fervently - the kind of data of which we have provided perhaps a surfeit regarding the Cemetery Cult and a substantial amount regarding the Noise. Nor do we know what Wind Nation will become. Will it (again) pursue theocratic ends via electoral politics? Could it become the tool of cynics interested only in secular political power? Will it become an institution that combines millenarian hopes with such pragmatic endeavours as forging ties with international non-government 
organisations? We know with certainty, however, that it will face the challenge of sustaining adherents' commitment to a millenarian doctrine even as salvation remains stubbornly out of reach.

For Manus people and other Papua New Guineans drawn to millenarianism but not to Wind Nation, Christian organisations offer many options. Almost all Papua New Guineans claim affiliation with some form of Christianity, although there are no precise data on their distribution among denominations and sects. ${ }^{26}$ We do know that a growing percentage of Christians worldwide are adherents of evangelical, charismatic, or Pentecostal groups-for most of which Christ's Second Coming is a central tenet of belief (Ernst 2012) ${ }^{27}$-and that the same trend is evolving in PNG. Richard Eves (2008: 2) observes that 'regardless of its high proportion of Christians, Papua New Guinea is one of the most evangelised places in the world. Currently, thousands of missionaries are spreading the gospel, often to people who have long identified themselves as Christian. The religious orientation of these missionaries is largely evangelical, charismatic or Pentecostal'. Wind Nation has already lost members to strongly millenarian Christian sects, as we noted in Chapter 13, and will probably find it hard to compete with such sects, many of which have the support of international organisations and prominent PNG politicians (see e.g. Eves 2008: 2; Eves et al. 2014). ${ }^{28}$ Yet, ironically, although Wind Nation grew from that most ridiculed form of millenarianism, the cargo cult, and it rejects God, it looks like a more humane choice than do many of the rising millenarian Christian sects in PNG that claim firm biblical roots. Citing parallels with Pentecostalism in Africa, John Cox (2014: 11) warns of their implication in what he calls 'intensification of fears of sorcery and witchcraft and the attendant accusation and killing of witches' (cf. Forsyth and Eves 2015; Rio et al.

26 Exceptions include Muslims and followers of the Baha'i faith, each representing less than 1 per cent of the population, and those who profess no affiliation (Gibbs 2014). Richard Eves (2008: 2) reports that 'fundamentalist groups are increasing in influence throughout Papua New Guinea' and cites, with caution, Operation World, 'an organisation with a primary focus on the power of prayer', which estimates that about 97 per cent of the PNG population 'identifies itself as Christian', and about 43 per cent of PNG Christians are evangelicals, charismatics, or Pentecostals.

27 There is disagreement, however, about when and how this will occur (see e.g. Boyer 1992; Carter 2010). And — at least among American Christians_-belief in the Second Coming extends far beyond evangelicals (Heimlich 2010).

28 Pentecostalism and charismatic Christianity are products of American evangelical Christianity but have long since spread throughout the world, especially the global South. 
2017). ${ }^{29}$ Paliau often treated people harshly and invoked the occult for his own ends, but we find it next to impossible to imagine either Paliau or his Wind Nation successors indulging in such cruelty. Within the world of millenarian movements, Wind Nation may prove to be among the more innocuous.

We are not, however, sanguine about millenarianism in general in Melanesia, including Robbins's 'everyday millenarianism'. We are also much less sanguine than Jean Comaroff (2010) about the burgeoning popularity of Christian millenarianism in the world at large. She writes: 'The spirit of revelation is among us once more ... The genius of the new holistic faiths is to address the displacements and desires of the current world, to make its pathologies and terrors the portents of imminent transcendence' (ibid.: 33). Comaroff calls on 'social critics' to 'make cogent sense of this history in the making'. We insist that to do so one must keep firmly in mind that if there is a 'genius' in millenarianism, that genius is not necessarily benign.

29 Eves and Forsyth (2015: 6) write that the perception that 'malign ways of causing illness and death are spreading' is becoming more widespread in 'a number of Melanesian countries'. But, they argue: 'the sorcery and witchcraft of today are not manifestations of traditions that have continued unchanged for centuries. Rather, these beliefs wax, wane and change with changing circumstances and contexts. Thus, the way that sorcery and witchcraft are manifested in the contemporary situation is very much a product of more recent history, not timeless tradition' (p. 2). The 'contemporary situation' to which Eves and Forsyth refer is one in which new forms of poverty and inequality attending drastic economic change are thriving. But, even as they wax and wane, Melanesian perceptions of sorcery and witchcraft retain their roots in a view of the world that predates current political and economic turmoil—a view of the world as a place of omnipresent danger from conscious entities in which impersonal forces and chance play very minor roles. Eves and Forsyth illustrate this when they refer to Jason Hickel (2014: 108) on perceptions of sorcery and witchcraft in South Africa, where—as Eves and Forsyth echo Hickel—people 'interpret the failure to prosper economically not as a neutral market outcome or the product of chance, but as something that is orchestrated by specific human agents'. 
This text is taken from Like Fire: The Paliau Movement and Millenarianism in Melanesia, by Theodore Schwartz and Michael French Smith, published 2021 by ANU Press, The Australian National University, Canberra, Australia.

doi.org/10.22459/LF.2021.15 